\title{
Physiological and Psychosocial Health among Adults with Mental Disability: A Mini Study 智障人士體適能與蓮動的認知
}

\author{
Ada S. Y. CHAN Bik C. CHOW \\ Department of Physical Education, \\ Hong Kong Baptist University, HONG KONG \\ 陳雪禜 周珵珠 \\ 香港浸會大學體育學系
}

\begin{abstract}
Obesity is an important worldwide public health problem and sedentary lifestyle has been associated with increasing rates of overweight and obesity. This presentation aims to study the relationship between psychosocial health, obesity and the lifestyle among the intellectual disability. A total of 16 adults over the age of 18 with mild to moderate intellectual disability (ID) (6 males, 6 females), ( $\mathrm{N}=16$, mean age 34.4.23 \pm 51 years, $\mathrm{SD}=8.67$ ), were recruited from St. James settlements. Pedometer step counts were recorded on 4 consecutive (week) days, BMI and waist circumstance were recorded. Questionnaires regarding adult's outcome expectation, perceived barriers to exercise and performance self efficacy on physical activity were examined. Result showed that adult with intellectual disability mean on total daily step counts was 7458.44 steps, ( $\mathrm{SD}=5048.19)$, the mean BMI is 26.43 , and both performance self efficacy and barrier to exercise among them were not high. The study concluded that both physiological and psychosocial health among adult with intellectual disability were low and more physical activity is needed.
\end{abstract}

\section{摘 要}

殘疾人士痴肥情況比一般普通成人嚴重, 而且平均壽命較短, 對健康的需求比較高。可是研究對於在職智障成年人的調查比 較少, 對於可行而且有效的運動計劃亦缺乏資料。為了提高在職智障成年人士的生心健康, 一項了解智障成年人士的運動量以及 他們對運動的態度的研究是需要的。是次調查對象為成年智能障礙人士, 級別為輕, 中度智障 (本研究不包括重, 極重度智能障 礙者)，所有參與者人士都是來自於聖雅各福群會，共有16位自願參與者而他們都是 18 歲以上成人，參與者平均年齡為 34.4 (23 土51歲, SD 8.67)。我們派發一個數步器（型狀跟傳呼機相似）給參與者, 數步器需佩戴在右邊腰身上連續4日, 在第五天早上 研究人員為參與者除去數步器, 並記錄總步行數量。同時我們亦派發一份有關活動量及對活動態度的問卷, 內容包括:對運動預 期結果，面對運動阻礙，對運動表現自我效能。調查所得出之結果顯示參與者平均每日步數為7458步 $(\mathrm{SD}=5048.19)$ 。脂肪比例為 26.4 , 面對運動阻礙 (Mean=1.8, $\mathrm{SD}=.39$ ) 和對運動表現自我效能 (Mean=.8, $\mathrm{SD}=.64)$ 顯示為不太高。結論是成年智障人士需 要在工作地方有一個運動課程從而提高他們生理和心理的健康發展、成長。

\section{Introduction}

\section{Important Effect of Obesity on Health}

Obesity is risk factor for chronic disease, a primary contributory risk factor for cardiovascular disease, and a significant contribution to the reduced life expectancy of adults with intellectual disabilities (Brown, Thomas, \& Kotecki, 2007). Apart from physiological aspects, exercise may have psychosocial outcomes from Intervention for special population, like decrease anxiety, decrease depression; enhance feelings of well-being; improve performance during work; and improve performance during 
recreational and sports activity (U.S. Department of Health and Human Services 2008).

\section{Obesity among Intellectual Disability}

In 2007, research findings showed that, prevalence of obesity in adults with intellectual disabilities is greater than that found in the general population which ranging from $11.7 \%$ to $26.5 \%$ in men with intellectual disabilities compared with $3.9 \%$ to $23.1 \%$ of men in the general population, and the prevalence of obesity of women with intellectual disabilities $23.1 \%$ to $58.5 \%$ compared with females in the general population with $3.6 \%$ to $28 \%$ (Hamilton, S. 2007). In Hong Kong there is relatively little information on the physical activity patterns of the workers with disabilities. When compare with normal population, researcher stated that life expectancy of persons with intellectual disability generally dies at an earlier age than those adults in the general population (average age at death: 66.1 years) and the longevity for adults with Down syndrome is 55.8 in average age at death.

Besides, obesity is more prevalent in adults with intellectual disabilities than in the general population. For general population, male adult with obesity rate $3.9 \%$ to $23.1 \%$, female adult is $3.6 \%$ to $28 \%$; for special population, male is $11.7 \%$ to $26.5 \%$, while female is $23.1 \%$ to $58.5 \%$ (Hamilton, S. 2007).

\section{Background Information of Disable Population in Hong Kong}

In 2000, there were 269,500 people are in restricted body movement, seeing difficulty, hearing difficulty, speech difficulty, mental illness and/or autism in Hong Kong. Within 269,500 of disabled persons, about 62,000 to 87,000 people (23-32\% of special population) are mentally handicapped (Hong Kong Special Administrative Region Government, 2008). In this special population, finding indicated that disabled persons have a sedentary lifestyle, the daily activity of disabled persons spent 3.6 hours/week on watching television, 2.2 hours/week in physical activity, 1.9 hours/week on pursuing hobbies and crafts, and 1.8 hours/ week on visiting relatives (Fu, 1996).

For employment opportunity, Hong Kong Government provide some employment services for mentally handicapped persons aged 15 or above with day training or vocational rehabilitation service, like day activity centre, sheltered workshop, supported employment, integrated vocational rehabilitation services centre, integrated vocational training centre (day service), on the job training programme for people with disabilities, enhancing employment of people with disabilities through small enterprise' project called Sunnyway, and work extension programme. However, the job nature in day training or vocational rehabilitation is usually a sitting job that may reinforce sedentary lifestyle for people working there (Social Welfare Department 2008). With a number of disabilities workers in Hong Kong, research attention is needed to address their physical activity level; however, this issue has not been explored in adult with intellectual disability. In the light of decrease life expectancy and increase obesity and/or overweight, the present study was conducted that aimed to assess the psychosocial outcomes on physical activity and through using of pedometer, measure the activity level of adult with intellectual disability. With the better understand, it is believed that it might be beneficial to assess the effective ways for exercise protocols and help promoting health in this special population in Hong Kong.

\section{Definition}

According to The Diagnostic and Statistical Manual of Mental Disorders (DSM), the classification of intellectual disability refer to a significantly reduced ability to understand new or complex information, to learn new skills (impaired intelligence), with a reduced ability to cope independently (impaired social functioning); which started before adulthood, with a lasting effect on development (World Health Organization, 1980). There are many other thesaurus referring to intellectual disability: mental disability, mentally handicapped, mental deficiency, mental retardation, cognitive impairment, intellectual disability, learning disability and developmental disability. In UK, learning disabilities or learning difficulty will be normally being used; and in North America, developmental disability, mental retardation and mental handicap is usually used; while in Hong Kong, mentally handicapped, intellectual disability is more prevalent. In fact, since 1876 American Association on Mental Deficiency had renamed into American Association on Mental Retardation and American Association on Intellectual and Developmental Disabilities at 2006. Intelligent Quotient (I.Q.) is divided into four types, Mild grade: I.Q 50-55 to 70; Moderate grade: I.Q 35-40 to 50-55; Severe grade: I.Q 20 to 35 ; and Profound grades: I.Q $<20$. 


\section{Methods}

\section{Participants}

A total of 16 adults over the age of 18 with mild to moderate intellectual disability (ID) $(6$ males, 6 females), $(\mathrm{N}=16$, mean age $23 \pm 51$ years, $\mathrm{SD}=$ 8.67), were recruited from St. James settlements. Written consents from their parents or guardians were obtained before conducting the study.

Although IQ scores were not available, verification that the sample represented adult with mild to moderate ID was based on a center supervisors confirmation and then randomly selected to participate in this study.

\section{Procedures}

Activity data were collected by the sealed pedometer (Yamax SW700), Pedometer step counts were recorded on 4 consecutive (week) days with subjects wearing a pedometer on their right waist during waking hours except shower and swimming. Before data collection, 30-step test and 3-shake test were performed to test pedometer's accuracy and all the pedometers have replaced new batteries.

Test administrators collected the pedometer, activity data and recorded them onto the log book and give them another pedometer during a) every morning before subjects started their work and b) at the end of the work day. Administrators also need to record the his/her wake up time, bed time, time to work, time to off, transportation to work, time need to travel from home to office, activity and time after work. Height and weigh measures for the calculation of BMI and waist circumstance were recorded.
Psychosocial data were assessed by a questionnaire(Heller, Marks, \& Sisirak, 2006) about outcome expectation, perceived barriers to exercise and performance self efficacy on physical activity. Outcome expectations includes 9 items; Control weight, feel less tired, make body feel good, feel happier, hurt less, meet new people, get in shape, look better, and improve health. Instrument measured on a 3-point Likert scale. The reliability is .79 .

Barriers scale includes 9 items about barriers towards exercise participation. The barriers include lack of time, lack of interest, lack of energy, perception that exercise is boring, will not improve condition, will make condition worse, is too difficult, has health concerns, and are too lazy. It is rated on a 3-point Likert scale from 1 (not a barrier) to 3 (yes, a barrier) for the person with intellectual disability. The reliability is .73. And the Self-Efficacy Scale contains 5 items pertaining to the confidence that one has in performing exercise, including being able to use various kinds of exercise equipment and feeling comfortable performing strength and cardiovascular exercises. Confidence is rated on a continuum from 1 (not at all sure) to 3 (totally sure). The reliability is .91 .

\section{Results}

All participates have completed the test (6 males, 6 females), $(\mathrm{N}=16$, mean age $23 \pm 51$ years, $\mathrm{SD}=8.67)$, Most of the participants are living in Hong Kong Island, they usually take school bus or tram to work (mean time to work $30 \pm 40$ mins). The mean wake up time is $7 \mathrm{am}$ and bed time at $10 \mathrm{pm}$ (mean sleeping hours 9 hours). Findings showed that the mean time start work at 8:10 am, and off at 4:00 pm (mean working hour 7.7 hours); and the mean walk count during office hour is 2674steps, $\mathrm{SD}=1962.47$. and the mean time off work at 4:00 pm, and sleep at 10:00 pm. (mean leisure hour 7.7 hours); and the mean walk count during leisure hour is 4784.3steps, $\mathrm{SD}=5676.68$. Most of the participants will have activity after work, that usually were housework less than 15 minutes in their non-working time and the mean on total daily step counts was 7458.44steps, (SD=5048.19) (See Table 1). 
Table 1. Working Hours and Physical Activity among Participants (Mean).

\begin{tabular}{lccc}
\hline Variable & Working Hour & Non-Working Hour & Mean Total Step per Day \\
Physical Activity (Daily): & & & \\
Hours & 7.7 & 7.2 & 14.9 \\
Step & 2674 & 5676 & 7458 \\
\hline
\end{tabular}

From the findings, adult with intellectual disability have more walking steps count in non-working time compare with the steps at working time, and was considered to be low active in physical activity level. The result from BMI showed that most of the participants were considered as obese. The mean BMI is 26.43. and the mean waist circumference for male is 34 , and for female is 35 . these indicate that both men and women among ID abdominal fat is high and that will have health risk increases (See Table 2). When sum up with both BMI and waist circumstance, findings also showed that both male and female were classified as overweight, which male were in increased risk of disease and female were in high risk of disease.

Table 2. Anthropometric among Participants (Mean).

\begin{tabular}{llcc}
\hline Variable & $\begin{array}{c}\text { Male } \\
(\mathrm{n}=8)\end{array}$ & $\begin{array}{c}\text { Females } \\
(\mathrm{n}=8)\end{array}$ & Total Mean \\
\hline Anthropometric: & & & \\
Age & 30.7 & 38 & 34.4 \\
Height (cm) & 159 & 154 & 156 \\
Weight (kg) & 63 & 66.1 & 65 \\
BMI (kg/m2) & 25 & 28 & 26.4 \\
Waist Circumference (inches) & 34 & 35 & 34.4 \\
\end{tabular}

Questions on psychosocial: outcome expectation (Mean=2.6, $\mathrm{SD}=.36$ ), barrier to exercise (Mean=1.8, $\mathrm{SD}=.39$ ), and performance self-efficacy (Mean=.8, $\mathrm{SD}=.64)$. showed that outcome expectation among adult with Intellectual disability is quite high, while performance self efficacy and barrier to exercise among them were in middle (See Table 3).

Table 3. Psychosocial Aspect towards Physical Activity among Participants (M, SD).

\begin{tabular}{lcc}
\hline Variable & Mean & SD \\
\hline Outcome expectation & 2.6 & 0.36 \\
Barrier to exercise & 1.8 & 0.39 \\
Performance self-efficacy & 0.8 & 0.64 \\
\hline
\end{tabular}




\section{Discussion}

Comparing with general population, adults with intellectual disabilities have high risk in obesity, and it shown to be a risk factor affecting health and longevity. Study on effectiveness on weight loss intervention among adult with intellectual disabilities in Hong Kong is paucity. To develop an effective and applicable exercise intervention for adults with intellectual disabilities, there is a need to have a better understanding on health status, psychosocial pattern and physiological status among them.

In 2004, research findings showed that adults with intellectual disability were significantly less active, data also showed that the average number of minutes of moderate-to-hard physical activity accrued per day is on average 10 minutes less than the level recommended for health (Frey, G. C. 2004) and in 2006, findings on physical activity of adults with intellectual disability showed that only one third or fewer of them were sufficiently active to meet the various health promotion guidelines for physical activity and to achieve health benefits (Temple, Viviene, A. 2006). There is a need to find ways to get people with disabilities more involved in physical activity, particularly person with intellectuality disable.

In this study, we find that among Hong Kong Chinese subjects, about $12.5 \%$ of men and $25 \%$ of women are generally obese while $25 \%$ of men and $43.75 \%$ of women go beyond the healthy standard of waist circumstance (Hong Kong: Department of Health, 2008), consider to be very severe. Compared to general working population, the condition is worrying especially in female, the percentage of female obesity (25\%) in this study is almost double in general female (13.6\%) which is $11.4 \%$ higher (Hong Kong: Department of Health, 2008). However, the percentage of ID men obesity (25\%) lowers than the general obesity among men population (32.2\%) (Hong Kong: Department of Health, 2008).
When comparing the waist circumstance with general population in 2007 (Tin-choi et al., 2007), obesity and severe obesity in Hong Kong Chinese working population were $35 \%$ and $26.7 \%$ in men and $21.7 \%$ and $26.7 \%$ in women respectively; while in this study, obesity and severe obesity among the subjects were $25 \%$ and $25 \%$ in men and $43.75 \%$ and $6.2 \%$ in women respectively. Again, great difference was found in female obesity rate, that female subjects $(43.5 \%)$ are $21.8 \%$ higher than the general female working population (21.7\%). In conclusion, among women, the percentage of obesity is serious especially in intellectual disabilities; while comparatively, the percentage of obesity among men with intellectual disability is not.

Comparative data for general population using equivalent measures for psychological is not available; however, the results suggest a similar outcomes that found in the special population that barrier to exercise (Mean=1.8, $\mathrm{SD}=.39$ ), and performance self-efficacy (Mean=.8, $\mathrm{SD}=.64$ ). are not high enough (Cardinal, Kosma, \& McCubbin, 2004).

This study had a few limitations. While the results were based on mild to moderate grade wearing pedometer for 4 consecutive days, the validity of the data is reflected in the face that adults with intellectual disability were obese. However, the results for the adults who were unable to wear the pedometer themselves were excluded from our study (severe grade) may be different from what was described here. And the results only reflect the number of step during weekdays, there is no data on weekends (Saturday and Sunday). Further work on identifying activity level and the physical activity pattern on weekends is the next step towards reducing weight problem and risk of health in the lives of adult with intellectual disabilities. 


\section{Reference}

Brown, K. M., Thomas, D. Q., \& Kotecki, J. E. (2007). Physical activity and health: An interactive approach (2nd ed.). Jones and Barlett Publisher.

Cardinal, B. J., Kosma, M., \& McCubbin, J. A. (2004). Factors influencing the exercise behaviour of adults with physical disabilities. Medicine \& Science in Sports \& Exercise, 36, 868-875.

Frey, G. C. (2004). Comparison of physical activity levels between adults with and without mental retardation. Journal of Physical Activity and Health, 1, 235-245.

Fu, F. H. (1996). Attitudes towards and participation in sport and physical activity- A survey among disable persons No. FS-VF1873). Hong Kong: Hong Kong Baptist University.

Hamilton, S., Hankey, C. R., Miller, S., Boyle, S., \& Melville, C. A. (2007). A review of weight loss interventions for adults intellectual disabilities. The International Association for the Study of Obesity. Obesity Reviews, 8, 339-345.

Heller, T., Marks, B., \& Sisirak, J. (2006). In Rehabilitation Research and Training Center on Aging with Developmental Disabilities (Ed.), Exercise and nutrition health education curriculum for adults with developmental disabilities. RRTCADD (3rd ed.). University of Illinois at Chicago.

Hong Kong: Department of Health. (2008). Statistics on behavioural risk factors. Retrieved April 29, 2009, from http://www.chp.gov.hk/

Hong Kong Special Administrative Region Government. (2008). Hong Kong: The facts rehabilitation (White Paper on Rehabilitation. Hong Kong: The Information Services Department.
Social Welfare Department. (2008). Services for mentally handicapped persons. Retrieved 09 April, 2009, from http://www.swd.gov.hk/en/index/site_pubsvc/page_rehab/ sub_listofserv/id_enhancinge/.

Temple, V., A., Frey, G. C., \& Stanish, H., I. (2006). Physical activity of adults with mental retardation: Review and research needs. American Journal of Health Promotion, 2(1), 2-12.

Tin-choi, K. O. G., Juliana, C., Amy, C., Patrick, W., Stanley, H., \& Ferrie, C., et al. (2007). Doubling over ten years of central obesity in Hong Kong Chinese working men. Chinese Medical Journal, 120(13), 1151-1154.

U.S. Department of Health and Human Services. (2008). 2008 physical activity guidelines for Americans. Retrieved February, 7, 2009, from http://health.gov/ paguidelines/guidelines/default.aspx

World Health Organization. (1980). Diagnostic and statistical manual of mental disorders. Washington, DC: American Psychiatric Association.

\section{Correspondence:}

Contact author: Ada SY Chan Address: Department of Physical Education, Hong Kong Baptist University, 13/F, 8 On Muk Street, Shatin, Hong Kong. 